\title{
Ukrainian Studies in Canada since the 1950s: A Brief Introductory Note to Part II
}

\author{
Roman Senkus
}

Canadian Institute of Ukrainian Studies, Toronto Office, University of Alberta

$\mathrm{V}$

olodymyr Kravchenko's article on the formative years of the Canadian Institute of Ukrainian Studies and Jaroslav Skira and Fr. Myroslaw Tataryn's essay on Canadian contributions to Ukrainian church history and theological studies constitute part II of the special thematic section on "Canadian Contributions to Ukrainian Studies in Canada since the 1950s" that was published in volume 5, number 1 (2018) of EWJUS. We thank Professors Kravchenko, Skira, and Tataryn for their participation in this discussion.

The special thematic section of vol. 5, no. 1, 2018, can be accessed at https://www.ewjus.com/index.php/ewjus/issue/view/13/showToc. It contains articles that describe contributions of Canadian scholars to Ukrainian studies in the fields of ethnography, history, linguistics, and political science, and report on CIUS's activities in the period 1992-2012.

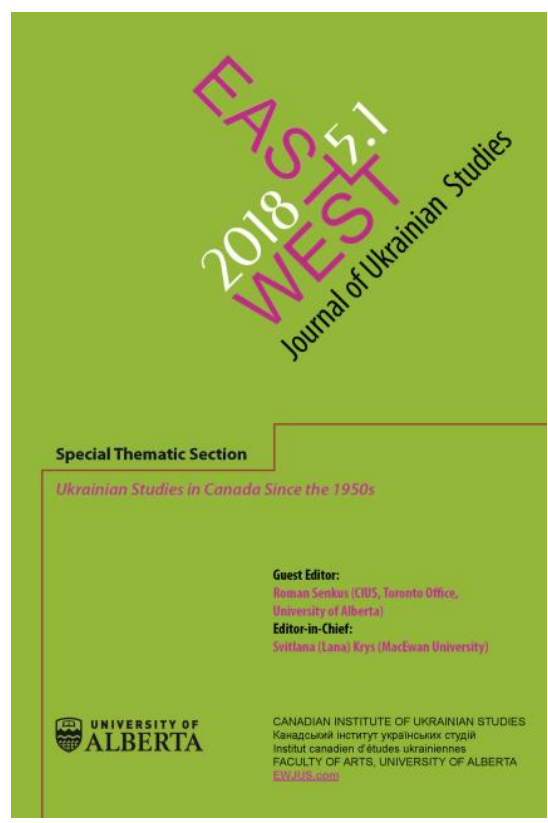

